\title{
MALARIA SURVEILLANCE IN THE ANAK DALAM TRIBE, JAMBI, INDONESIA
}

\author{
Ade Suryaman, ${ }^{1 *}$ Chairil Anwar, ${ }^{2}$ Dwi Handayani, ${ }^{2}$ Irsan Saleh,,${ }^{3}$ Dalillah, ${ }^{2}$ \\ Gita Dwi Prasasty, ${ }^{2}$ Ahmad Giffari, ${ }^{4}$ Sulfa Esi Warni ${ }^{5}$ \\ ${ }^{1}$ Politeknik Kesehatan Kemenkes Jambi, Jambi, Indonesia. \\ ${ }^{2}$ Department of Parasitology, Faculty of Medicine, Sriwijaya University, South Sumatra, 30126, Indonesia \\ ${ }^{3}$ Department of Pharmacology, Faculty of Medicine, Sriwijaya University, South Sumatra 30662, Indonesia \\ ${ }^{4}$ Department of Parasitology, Faculty of Medical Science, Universitas Muhammadiyah Palembang, South \\ Sumatra 30263, Indonesia \\ ${ }^{5}$ Baturaja Health Research and Development Center, East Batu Raja, South Sumatra 32111, Indonesia.
}

\begin{abstract}
Transmission of malaria is common in countries with tropical and subtropical. In several cases, malaria presents in the sufferer especially in individuals that have never received treatment shortly. As the early phase of patient identification, screening is important as an effort to eradicate malaria, in addition to the gold standard which currently used, other diagnostic tools are needed to conduct a malaria incidence survey to obtain comparative data using 3 diagnostic tools, goal standard checks, which are currently unable to detect asymptomatic malaria. This study aims to compare three standard diagnostic test (Rapid Diagnostic Test, Giemsa, and Nested Polymerase Chain Reaction) for the measurement of malaria prevalence within the Anak Dalam Tribe community in Jambi, Indonesia. This descriptive research with a survey design was conducted on 99 persons in Anak Dalam Tribe. It was discovered that majority of the respondents were the adult age category (52.5\%), were female (50.5\%). The prevalence of this infectious disease as detected by Rapid Diagnostic Test, microscopy, and Nested Polymeras Chain Reaction examination were 3\%, 5\% and $35.3 \%$ respectively. Non-Plasmodium falciparum was detected by examining samples with Rapid Diagnostic Test, on microscope, P. vivax and P. falciparum were found, while on Nested Polymerase Chain Reaction, two bands at 120bp and 205bp showed P. vivax and P. falciparum respectively. Nested Polymeras Chain Reaction is more sensitive to detected asymptomatic malaria, however, Rapid Diagnostic Test and Giemsa sensitive with parasitemia threshold.
\end{abstract}

Keywords: anak dalam tribe, giemsa stain, malaria, polymerase chain reaction, and rapid diagnostic test

\begin{abstract}
ABSTRAK
Penularan malaria sering terjadi di negara-negara tropis dan subtropis. Dalam beberapa kasus, malaria muncul pada penderitanya tanpa gejala, terutama pada individu yang tidak pernah mendapatkan pengobatan dalam waktu dekat. Skrining malaria sebagai awal identifikasi pasien penting dilakukan sebagai upaya pemberantasan malaria, selain baku emas yang saat ini digunakan, diperlukan alat diagnostik lain untuk melakukan survei kejadian malaria untuk mendapatkan data pembanding menggunakan 3 alat diagnostik, pemeriksaan dengan baku emas saat ini tidak dapat mendeteksi malaria asimptomatik. Penelitian ini bertujuan untuk membandingkan uji diagnostik (Rapid Diagnostic Test, Pewarnaan Giemsa, dan Nested Polymerase Chain Reaction) untuk pengukuran prevalensi malaria pada suku anak dalam, Jambi, Indonesia. Penelitian deskriptif dengan desain survei ini dilakukan pada 99 orang di suku anak dalam. Ditemukan bahwa mayoritas responden adalah kategori usia dewasa (52,5\%), dengan jenis kelamin perempuan (50,5\%). Prevalensi penyakit menular ini yang terdeteksi dengan pemeriksaan rapid diagnostic test, mikroskop, dan nested nested polymerase chain reaction berturut-turut adalah 3\%, 5\% dan 35,3\%. Non-plasmodium falciparum terdeteksi dengan memeriksa sampel dengan metode rapid diagnistic test, pada mikroskop ditemukan P. vivax dan P. falciparum, sedangkan pada nested nested polymerase chain reaction, dua pita pada $120 \mathrm{bp}$ dan 205bp masing-masing menunjukkan P. vivax dan P. falciparum. Nested nested polymerase chain reaction lebih sensitif untuk mendeteksi malaria tanpa gejala, namun rapid diagnostic test dan Giemsa sensitif pada malaria dengan ambang parasitemia.
\end{abstract}

Kata kunci: suku anak dalam, pewarnaa giemsa, malaria, polymerase chain reaction, dan rapid diagnostic test.

Correspondece Address: Ade Suryaman, Politeknik Kesehatan Kementerian Kesehatan Jambi, Indonesia, E-mail: adesuryaman@poltekkesjambi.ac.id 


\section{Introduction}

Malaria is the most predominant human protozoan infection in the world, since at the present, its burden remains high globally. ${ }^{1}$ Furthermore, the transmission of malaria is common in countries with tropical and subtropical climates. There were 217 and 219 million cases in the world in 2016 and 2017 respectively. Also, 3-4 billion people in 92 countries were highly susceptible to this disease, and the number of those that died was 435,000. The highest occurrence recorded was in Africa, with an estimated death rate of $93 \%$, while $61 \%$ of the cases occurred in children under 5 years. $^{2}$

In Indonesia, the morbidity caused by malaria has decreased from 0.99 per 1000 population to 0.68 between 2017 and 2018 with a total number of 180,205 people that tested positive. Jambi is one of the provinces of Sumatra in this country, which has a morbidity rate of 0.03 per 1000 population with up to 121 positive individuals. ${ }^{3}$ The endemic areas in this region are generally remote villages with poor environmental conditions, difficult access to communication and transportation facilities, unavailability of health services, low socio-economic and educational levels, as well as poor community behavior towards healthy living. Meanwhile, the Batang Hari Regency has the highest value of 0.042 cases per 1000 people. ${ }^{4}$

Malaria often presents without symptoms, which is asymptomatic, especially in individuals that have never received treatment shortly. ${ }^{5}$ Furthermore, the inability to visibly observe this condition in sufferers is due to the body's immune system that controls parasites, even though it does not completely heal, as there could be persistent fever or sometimes no sign at all. Parasitic density is the reason why the causative organism of this disease cannot be detected by rapid diagnostic test, and microscopic examination, but can be identified by polymerase chain reaction. ${ }^{6,7}$

There are several types of malaria tests that can be done, which include "Gold standard" of Plasmodium examination by microscopy using Giemsa staining. In addition, correct identification of the four species that cause such infection in humans and the level of detection with a microscope are highly dependent on the examiner's experience, proper staining, proper handling of the device, and time spent to check each slide ${ }^{8,9}$ RDT is one of the diagnostic technologies for the aforementioned test which combines immunochromatographic capture procedures with conjugated monoclonal antibodies that provide indicators of infection. It is considered to be quite sensitive with a parasitic density of 500/ $\mu$ compared to the gold standard, but the sensitivity diminishes with decreasing density. ${ }^{10,11,12}$

Another method of diagnosis is PCR, which is an examination technique that involves the synthesis of nucleic acids or certain genes enzymatically, in order to obtain double of the genetic material of certain species. Therefore, making this process to be very accurate and specific to 
Plasmodium sp species contained in erythrocytes. ${ }^{13}$ Multiplex PCR is often used for confirmation in laboratory diagnosis of malaria when examination with Giemsa is considered vague and dubious. ${ }^{14}$ Furthermore, this method is also very good when used in comparative studies for measuring the sensitivity of diagnostic tools between RDT and microscopy. ${ }^{10}$ This polymerase chain reaction has several advantages in detecting plasmodium compared to real-time polymerase chain reaction. ${ }^{13}$

Anak Dalam Tribe is situated in the interior of the Jambi forest, with a population of 3,205 people living in the administrative area of the following regencies; Merangin, Sarolangun, Batang Hari, Tanjung Jabung Barat, Tebo and Bungo in 2010. Due to their location, ADT are very vulnerable to malaria. ${ }^{15,16}$ The lack of information is due to the nomadic culture of this tribe, thereby making it difficult to obtain accurate data on overall health status. ADT dweels in biodiverse forests such as long-tailed macaques allow cross-infection, with poor environmental conditions, difficult access to communication and transportation facilities, unavailable health services, low socio-economic and educational levels, as well as poor community behavior towards healthy living. The impact of the lifestyle of these people, where they sleep outdoors, can potentially cause malaria. Meanwhile, the examination has been carried out using the RDT and microscopic methods. In addition to the current gold standard, other diagnostic tools are needed to conduct a survey of malaria incidence on ADT to obtain comparative data using three diagnostic tools, namely RDT, Giemsa, and Nested PCR. Furthermore, there is a need for other examination methods that are more sensitive and specific to detect malaria, including asymptomatic malaria. This study aims to identify the prevalence of malaria within the ADT community in Jambi by using the three examination techniques Rapid Diagnostik Test, Giemsa stain, and Nested Polymerase Chain Reaction.

\section{Method}

Descriptive research with a pattern of survey was conducted in the Terap River region Jelutih Village, Batanghari Regency, Jambi Province from October $1^{\text {st }}$ to November $30^{\text {th }}, 2019$. Microscopic and molecular examinations were conducted at the Laboratory of Health Research and Development Center Baturaja, Indonesia.

The participants were all of ADTs who were in Bukit 12 forest, Sungai Terap Jelutih village, Batanghari district who could be met at the time of sampling based on inclusion criteria which were willing to take a blood sample and the exclusion criteria is the people who had taken malaria medicine before blood sampling, then the sample size was using a total sampling with the size of 99 which met the inclusion criteria. Afterward, all the respondents carried out 3 types of examinations, namely RDT, Microscopic and Nested PCR to assess the existence of malaria. 
This study began with an explanation of the research at the chieftain's domain, and respondents were selected according to the inclusion criteria. After obtaining approval, they were asked about any complaints of shivering fever, while sampling was carried out by Balitbangkes Baturaja Jambi laboratory experts. Specimens were obtained from peripheral blood at the fingertips, which was preceded by an RDT, then making thin and thick sample preparations, followed by blood dropping on a filter tissue for Nested PCR. Microscopic test was also performed by WHO certified lab professionals who were specialized in malaria examination. However, screening for nesting with the polymerase chain reaction was carried out by PCR specialists. Ethical approval was obtained from the Faculty of Medicine, Universitas Sriwijaya Ethics Committee (No. 505/KEPKRSMHFKUNSRI/2019).

Standard form of RDT was used for malaria diagnosis in ADT by the Indonesian Ministry of Health. The middle finger was electrified using an alcoholic cotton swab, and then autoclaved, while a lancet was used to pierce the finger. The blood that leaked out of the punctured skin at first was wiped off, but the next was obtained with a capillary pipette until it reached the limit mark of the tube. Then drops were made on the test kit and its buffer was added, while time and respondent code were recorded for up to 20 minutes. Whenever the control and line 1 are formed, presence of P. falciparum is indicated. But when there is formation of control, line 1 and 2, then the positive mixture of Plasmodium is signified. ${ }^{11}$

Thin preparations were made by placing one short side of a second glass object with a slope of 45 degrees right on top of the blood dropped on the first. Then waited a moment until the sample spread evenly on the side of the oblique glass, after which it was moved with a slight pressure to a stable angle of 45 degrees until there was a thin and even spread of the droplets. However, thick preparations were made by one drop of blood on a glass object which spreads out to form a circle with a diameter of 1-2 cm by using the angle of another glass. After it was dried, the thin preparations were fixed with methanol, but the counterpart was not. After fixation, both were immersed in $2.5 \%$ or $7.5 \%$ Giemsa for 45 minutes or 15 minutes, and then flushed with distilled water. After drying, they were observed under a microscope with an objective magnification of 100 times using immersion oil.

The procedures for this examination include (a) Cut the paper $(\leq 25 \mathrm{mg})$ into small pieces and place it on a $1.5 \mathrm{ml}$ microcentrifuge tube. Add an ATL buffer of $180 \mu \mathrm{l}$ and Proteinase $\mathrm{K}$ of $20 \mu \mathrm{l}$, vortex, and incubation at $56^{\circ} \mathrm{C}(1-3 \mathrm{~h})$ until there is complete lysis. For occasional vortex during incubation; (b) Add $200 \mu \mathrm{l}$ AL buffer. Ensure complete vortex for 15 seconds; (c) Incubate at $70^{\circ}$ C for 10 minutes. Immediately centrifuge the tube to remove droplets on the lid; (d) Add $200 \mu$ of ethanol (96-100\%), then vortex for 15 seconds. Instantly centrifuge the tube to remove droplets on the lid; (e) Insert the mixture using a pipette into the QIAamp Mini spin column (in a $2 \mathrm{ml}$ collection tube). Centrifuge again at a speed of $6000 \mathrm{x} \mathrm{g}(8000 \mathrm{rpm})$ for 1 minute. Remove the 
flow-through and the collection tubes; (f) Position the QIAamp in a new $2 \mathrm{ml}$ collection tube and add a $500 \mu \mathrm{l}$ AW1 buffer, and centrifuge at same rate as the previous for 1 minute. Remove the two tubes; (g) Position the QIAamp Mini spin column in a new $2 \mathrm{ml}$ collection tube and add a $500 \mu \mathrm{l}$ AW2 buffer. Centrifuge at full speed $(20,000 \times$ g 14,000 rpm) for 3 minutes. Remove the flowthrough and collection tubes; (h) Position the QIAamp in another new $2 \mathrm{ml}$ collection tube (not provided) and centrifuge at full speed for 1 minute. This is to avoid the possibility of the AW2 buffer getting carried away; (i) Position the QIAamp in a new $1.5 \mathrm{ml}$ collection tube (not provided), add $200 \mathrm{AL}$ pure Aades or Aquades buffer and incubate at room temperature for 1 minute. Centrifuge at $6000 \mathrm{xg}(8000 \mathrm{rpm})$ for 1 minute to elute DNA.

These were compiled and analyzed using the Statistical Package for Social Sciences version 21 software. All the data were presented descriptively, including malaria prevalence variables and Plasmodium species.

\section{Results}

\section{Characteristic of respondents}

Based on table 1 below, it was recorded that the majority of respondents was the adult age category (52.5\%), with female sex $(50.5 \%)$

Table 1. Respondent Characteristics $(n=99)$

\begin{tabular}{lc}
\hline Characteristics & $\mathbf{n ( \% )}$ \\
\hline Age (year) & \\
Children $(2-10)$ & $38(38.4 \%)$ \\
Adolescent $(11-19)$ & $8(8.1 \%)$ \\
Adult $(20-60)$ & $52(52.5 \%)$ \\
Elderly $(60>)$ & $1(1 \%)$ \\
\hline Sex & \\
Male & $49(49.5 \%)$ \\
Female & $50(50.5 \%)$ \\
\hline
\end{tabular}

\section{Result of examination}

The table 2 below shows the respondents who performed the examination, whereby $3 \%, 5 \%$, and $35.3 \%$ were positive based on the RDT, microscopic examination of giemsa stain, and PCR test respectively.

Table 2. Result of RDT, Giemsa, Nested PCR tests $(n=99)$

\begin{tabular}{lcc}
\hline \multicolumn{1}{c}{ Test } & $\begin{array}{c}\text { Positive } \\
\text { n (\%) }\end{array}$ & $\begin{array}{c}\text { Negative } \\
\text { n (\%) }\end{array}$ \\
\hline Rapid diagnostic test & $3(3 \%)$ & $96(97 \%)$ \\
Giemsa stain & $5(5 \%)$ & $90(95 \%)$ \\
Nested polymerase chain reaction & $35(35.3 \%)$ & $64(64.7 \%)$ \\
\hline
\end{tabular}




\section{Prevalence of malaria based on RDT examination}

From the test on the samples, the results showed that there were 3 positive indications of Plasmodium non-falciparum (3\%) as shown in figure 1 below. C is control, while 2 is Anti-malarial antibody, and 1 is Anti-falciparum antibody, if a line appears on $\mathrm{C}$ only then it can be said to be negative, if a line appears on $\mathrm{C}$ and 2 then it can be said nun falciparum infection, whereas if a line appears on the three alphabet and numbers, namely $\mathrm{C}, 2$, and 1 , it can be said to be a falciparum infection. ${ }^{24}$

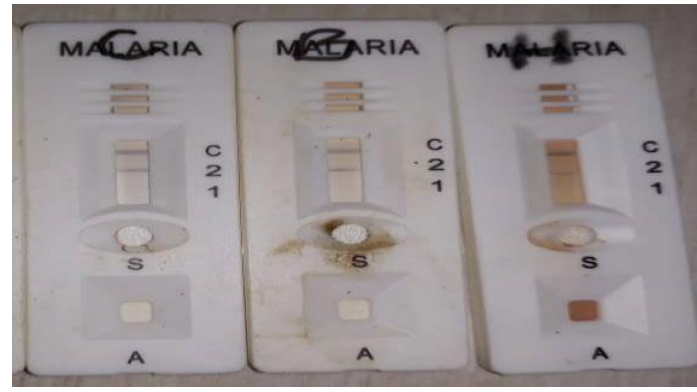

Figure 1. Sample RDT examination

(C: control; I: Non falciparum)

\section{Prevalence of malaria based on microscopic examination}

From the results obtained, 5 (5\%) of the samples, were positive for Plasmodium as shown in figure 2 below. In the blood smear, the trophozoid stage of the Plasmodium vivax parasite was found, a ring with irregularly shaped cytoplasm and Schuffner's point in red shadow was found.

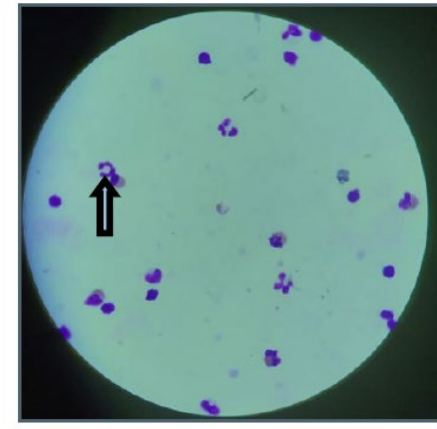

A

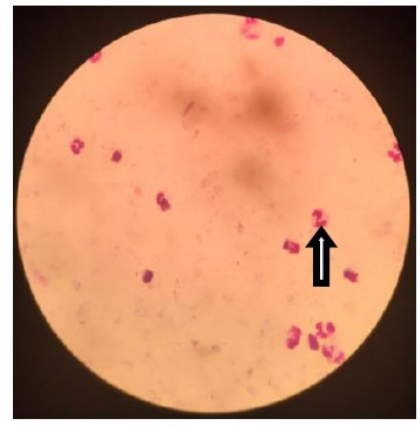

B

Figure 2. Microscopic examination

\section{The prevalence of malaria based on Nested PCR examination}

It was discovered that out of the samples tested, 35 (35.3\%) were positive, which include Plasmodium vivax (33.66\%), while only 1 showed a mixture of P. falciparum and P. vivax $(0.99 \%)$ as shown in the figure 3 below. 


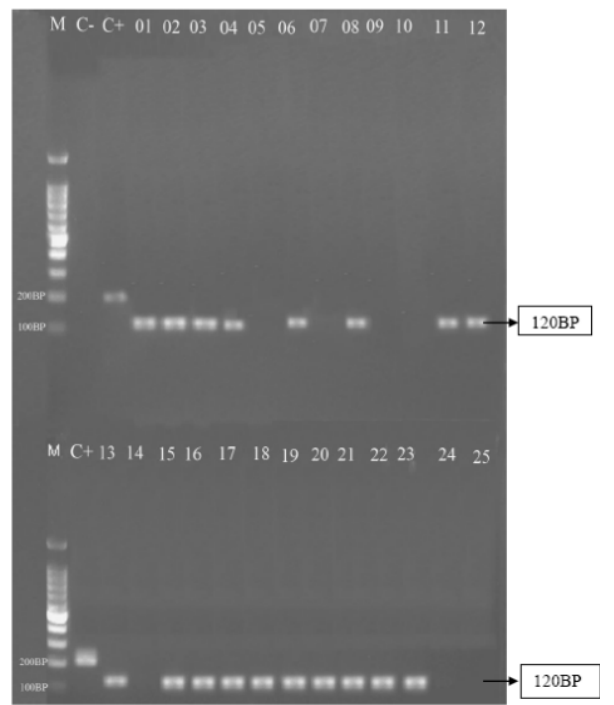

Figure 3. Nested PCR Visualization (M: marker; C-: negative control; C+: positive control of Plasmodium falciparum; 01-25: samples)

\section{Discussion}

The results generally indicated that the prevalence of malaria in the ADT Jambi Province, Indonesia were $2.97 \%, 4.95 \%$, and $34.65 \%$ by RDT microscopy and nested PCR examination respectively. From the ecological studies carried out on the breeding sites of this disease's vector, it was discovered that the topography and temperature of Batanghari Regency (a lowland and swampy area) is ideal for the proliferation of the organism, namely Anopheles SP mosquitoes which can enhance the risk of prevalence in $\mathrm{ADT}^{17,18,19}$. The discovery of people having parasitemia proves the existence of this vector which can complete the sexual life cycle of Plasmodium in itself and the asexual in human body. Therefore, this indicates high risk of infection amidst the tribe. ${ }^{20}$

A cross-sectional epidemiological study was performed to determine malaria endemicity in the Raub Orang Asli population, Pahang Malaysia, in which 520 research subjects were examined, and measurement was based on the widespread of parasitemia as well as splenomegaly. The prevalence rate was $24.2 \%$, while Plasmodium falciparum was $67.5 \%$ being the dominant species. Children below 12 years have 3.7 times more risk compared to those who were older, but individuals aged 2 to less than 10 years were about $38.1 \%$. The enlargement of the spleen among children of this category was $22.3 \%{ }^{21}$ The results showed that 3 positive non-falciparum were detected by RDT examination. Therefore, the prevalence of the infection in this region was $2.97 \%$ with a positive average age of 3.6 years on RDT examination. Children aged 1-5 years and pregnant women were vulnerable to malaria, thus, screening should be carried out by the health workers subsequently. ${ }^{22,23}$ Actually, in this study there was a similarity which showed that children aged below 5 years were very susceptible to the infection. ${ }^{22}$ RDT has the advantage of being able to quickly determine the state of parasitemia with a fairly high density, but is less able to detect at a 
low number of parasites, unlike the standard gold. Out of 54 samples with a parasitic density of $50,000 / \mu 1$, RDT detection in blood can be $100 \%$, while at $50 / \mu 1$, the detected value could be $75 \%$. It should be noted that, reduced detection ability is directly proportional to the decrease in parasitic density for each $\mu 1$ of blood. ${ }^{11}$

RDT is very easy for determining the state of parasitemia due to Plasmodium infection, with $95 \%$ detection capabilities, but this process is less sensitive in detecting non-P. falciparum. In evaluating the HRP-2 prototype test in Thailand and Peru, the P. falciparum detected was $100 \%$ for parasitic densities of $500 / \mu \mathrm{l}$ and $83 \%$ for less than $500 / \mu \mathrm{l}$. Roughly, the sensitivity will decrease with densities lesser than $500 / \mu 1$ of blood for P. falciparum and $5,000 / \mu 1$ of blood for P. vivax ${ }^{24}$. The prevalence study conducted in Equatorial Guinea with total specimens of 1,724 using microscope, RDT, and SnM-PCR showed that 128 RDT samples (13.3\%) were false negative when compared with PC. Hence, the reason some patients did not obtain anti-malaria treatment must have been due to whenever it is based on rapid diagnostic test alone. ${ }^{12}$

This study analyzed other types of examinations namely; microscopy and PCR. The first process was carried out on all samples, and 5 of the results obtained, showed the presence of the Plasmodium parasite, while 3 positive RDT specimens gave same indication with this technique. Therefore, the prevalence of the infection in this locality was $4.95 \%$ with an average age of positive respondents being 3.8 years. The level of detection with a microscope depends on several factors, which include the experience of the examiner, the right coloring of the slides, the proper care of the microscope, and the time spent in examining each slide. Microscopic examination can identify 1030 Plasmodium / $\mu$ l blood, at lower levels of parasitemia, which cannot be detected ordinarily. The level of this detection is not achievable in endemic conditions where many samples need to be examined in a short time. ${ }^{9,8}$ Thin preparations are used to detect the species of malaria parasites, but the thick is used to determine their presence.

Giemsa staining in mixed infection cases is considered difficult to correctly identify Plasmodium species, especially when the number of parasites that infect erythrocytes is small., ${ }^{9} 19$ This is because P. falciparum does not cause the enlargement of infected red cells, but only the ring forms and gametocytes can be seen in peripheral blood preparations, resulting to a high parasitemia because the total schizont produced is more than the other species. ${ }^{25}$ Besides, some types of Plasmodium have similar structures compared to other species such as P. knowlesi which are very similar to P. malariae and P. falciparum. ${ }^{19,25}$ Research carried out on blood supply archives in Sarawak, Malaysia, where several samples were tested positive for P. malariae based on microscopic examination, later turned out to be P. knowlesi on Polymerase Chain Reaction. ${ }^{26,27}$ Nested PCR examination was performed on all the specimens, including those that showed positive on RDT and microscopic evaluation. The results indicated that there were 5 positive on microscopic detection which also gave similar indication on the PCR, and there were 35 samples of 
which only 1 showed mixed infections. Therefore, the prevalence of this disease in the ADT as detected by overall polymerase chain reaction was $34.65 \%$ with an average age of 21.3 years of positive respondents who did not report any feverish complaints (asymptomatic). When sampling was performed, there were 5 research subjects who complained of fever and headache, but on PCR, a positive exposure to the Plasmodium parasite was indicated. This literature further explains that in the samples of those without complaints, it is possible there was no cytokine activity that usually appears during the rupture schizont phase. Furthermore, this triggers a lot of antigens to be responded to by the immunological system by releasing TNF and IL-6, in order that it can be interpreted as competent system immunology in suppressing the proliferation of Plasmodium in the asexual cycle of the intermediate host body. ${ }^{28}$

Although there is no specific definition of asymptomatic malaria, yet it can still be agreed that parasitemia does not show acute symptoms such as fever especially in individuals who have not undergone treatment in the near term, this concept applies to all the infected persons regardless of the level of transmission. ${ }^{5,7}$ This detection includes a parasitic increase that has not reached the pyrogenic threshold, in which the density of erythrocytes contaminated with Plasmodium is not sufficient to trigger an innate immune response and fever. Chronic malaria infection tends to have a much lower level of parasitemia compared to the symptomatic which cannot be detected by microscopic examination using Giemsa and RDT stains, but can only be identified by using PCR. This condition can last for several years, because with the use of rapid diagnostic test and microscopy for the detection, potentially $30 \%$ to $50 \%$ are lost compared to PCR. ${ }^{29,5}$ This situation is often considered favorable because individual's immunity tends to control parasites, while persistent infections can pose a great risk to children and pregnant women because of ability to aggravate other diseases. Reduced prevalence of asymptomatic malaria can subdue mortality and morbidity, on the spectrum. Furthermore, this infection can as well elevate the risk of unhealthiness, comorbidity, death rate, and subsequent transmission associated with increasing parasitemia density. Therefore, it is necessary to identify this condition, besides that, in the broader context it concerns the management strategies that aimed to perform elimination in order that the infection at any density can be detected and eventually treated. ${ }^{7}$

The ability of the immune system to control these parasites in the body causes the sufferers to be asymptomatic. Furthermore, the density caused by the competence of the individual's system is one of the reasons their presence cannot be detected by RDT, and microscopic examination, but can be identified by a more sensitive PCR..$^{30,29,31}$ This method is not used as a gold standard in testing, for this infectious disease because it can detect false positives in patients who have received anti-malaria treatment before, even though the parasite is no longer present. ${ }^{7,5}$ On the other hand, the PCR multiplex technique was considered to be more economical, high in detection capabilities, 
and specific for diagnostic methods that can be tested in malaria-endemic areas with higher sample sizes. ${ }^{13}$

RDT, microscopic, and nested PCR examination showed different results. The rapid diagnostic test results produced the least detection of positive Plasmodium because this technique experiences decreased ability when the parasitic density is low, that is less than $500 / \mu 1$ of blood for P. falciparum and 5,000/ $\mu$ l blood for P. vivax. ${ }^{10,30}$ Microscopic examination is a more detecting Plasmodium method compared to RDT, as a result, the prevalence rate obtained from this process is greater. This functions better in detecting malaria parasites especially when carried out by experienced and trained officers. With sufficient examination time, an examiner can detect 10-30 Plasmodium $/ \mu$ l blood. ${ }^{9}$

PCR examination detects the most Plasmodium when compared to the other two methods explained above. Even in subjects who do not experience any feverish symptoms, low parasitic density can still be detected by doubling the DNA chain in the PCR process. ${ }^{7}$ From the results of the above research, the prevalence of Plasmodium species is found highest as vivax. In general, they are often found in Asia as P. falciparum and P. vivax, but the results of the research conducted at the Thai border in 2008 and 2014 showed an increase in the spread of Plasmodium vivax parasites, and this must be a serious concern in the control of this infection. Therefore, research should be conducted to determine the genetic mutation of $\mathrm{P}$. vivax against anti-malaria drug such as artemisinin. $^{32}$

\section{Conclusion}

Nested PCR test it is more sensitive to detect malaria than RDT and Giemsa, and can even detect asymptomatic malaria in ADT. However, the drawback is that the PCR examination requires a higher cost, so it cannot be carried out at the public health center level. For further research, further research on the ADT immune response to asymptomatic malaria should be carried out. Treatment given in remote areas must be comprehensive, including asymptomatic cases to achieve malaria elimination.

\section{Acknowledgement}

Thank to Faculty of Medicine Universitas Sriwijaya and Baturaja Health Research and Development Center

\section{Funding}

In this study, researchers received a small portion of the funds from the PPSDM of the Ministry of Health. 


\section{Conflict of Interest:}

The authors declared no conflict of interest, and no funding was received for this study.

\section{Reference}

1. Pannu AK. Malaria today: advances in management and control. Trop Doct. 2019;49(3):160-4.

2. WHO. Malaria rapid diagnostic test performance: results of WHO product testing of malaria RDTs: round 8 (2016-2018). Geneva: World Health Organization; 2018. Vol. 3, WHO Publications. 2018. 154 p.

3. RI PD dan IKK. infodatin-malaria.pdf.

4. Dinas Kesehatan Kota Jambi. Profil Kesehatan Tahun 2017 Kota Jambi. 2017;(72):1-194.

5. Lindblade KA, Steinhardt L, Samuels A, Kachur SP, Slutsker L. The silent threat: Asymptomatic parasitemia and malaria transmission. Expert Rev Anti Infect Ther. 2013;11(6):623-39.

6. Sofia R. Malaria Asimtomatik: Tantangan Dalam. J Kedokt dan Kesehat Malikussaleh. 2015;85-92.

7. Chen I, Clarke SE, Gosling R, Hamainza B, Killeen G, Magill A, Magill W, O’Meara R, N. Price E, M. Riley. "Asymptomatic" Malaria: A Chronic and Debilitating Infection That Should Be Treated. PLOS Med. 2016;13(1):e1001942.

8. Nkrumah B, Agyekum A, Acquah SEK, May J, Tannich E, Brattig N, Nguah SB, Thien HV, Sarkodie YA, Huenger F. Comparison of the novel Partec rapid malaria test to the conventional Giemsa stain and the gold standard real-time PCR. J Clin Microbiol. 2010;48(8):2925-8.

9. Snounou G, Abdullah MS, Rahman HA, Singh B, Bobogare A, Cox-Singh J. A genus- and species-specific nested polymerase chain reaction malaria detection assay for epidemiologic studies. Am J Trop Med Hyg. 2017;60(4):687-92.

10. Juan Yan, Nana Li, Xu Wei, Peipei Li, Zhenjun Zhao, Lili Wang, Siying Li, Xiaomei Li, Ying Wang, Shuying Li, Zhaoqing Yang, Bin Zheng, Guofa Zhou, Guiyun Yan, Liwang Cui, Yaming Cao and QF. Performance of two rapid diagnostic tests for malaria diagnosis at the China-Myanmar border area. Malar J [Internet]. 2013;12(1):1-9. Available from: http://www.embase.com/search/results?subaction=viewrecord\&from=export\&id=L5246188 4\%0Ahttp://dx.doi.org/10.1186/1475-2875-1273\%0Ahttp://sfx.library.uu.nl/utrecht?sid=EMBASE\&issn=14752875\&id=doi:10.1186\%2F 1475-2875-12-73\&atitle $=$ Performance + of + two + rapid + dia

11. F. Van den Ende JBZG. Rapid diagnostic tests for malaria parasites. Clin Microbiol Rev [Internet]. 2002;15(1):66-78. Available from: 
http://www.ncbi.nlm.nih.gov/pubmed/11781267\%5Cnhttp://cmr.asm.org/cgi/reprint/15/1/6 6.pdf\%0Ahttp://www.ncbi.nlm.nih.gov/pubmed/11781267\%0Ahttp://www.pubmedcentral. nih.gov/articlerender.fcgi?artid=PMC1 18060

12. Berzosa P, De Lucio A, Romay-Barja M, Herrador Z, González V, García L, et al. Comparison of three diagnostic methods (microscopy, RDT, and PCR) for the detection of malaria parasites in representative samples from Equatorial Guinea 11 Medical and Health Sciences 1108 Medical Microbiology. Malar J [Internet]. 2018;17(1):1-12. Available from: https://doi.org/10.1186/s12936-018-2481-4

13. Miguel-Oteo M, Jiram AI, Ta-Tang TH, Lanza M, Hisam S, Rubio JM. Nested multiplex PCR for identification and detection of human Plasmodium species including Plasmodium knowlesi. Asian Pac J Trop Med. 2017;10(3):299-304.

14. Johnston SP, Pieniazek NJ, Xayavong M V, Slemenda SB, Wilkins PP, da Silva AJ. PCR as a confirmatory technique for laboratory diagnosis of malaria. J Clin Microbiol [Internet]. 2006;44(3):1087-9. Available from:

http://www.ncbi.nlm.nih.gov/pubmed/16517900\%0Ahttp://www.pubmedcentral.nih.gov/art iclerender.fcgi?artid=PMC1393165

15. Jambi DKP. Profil Kesehatan Provinsi Jambi Tahun 2015. Dinas Kesehatan Provinsi Jambi 2014. 2015.

16. Profil Suku Anak Dalam (SAD). Badanpusat Statistik Provinsi Jambi; 2010.

17. Rund SSC, O'Donnell AJ, Gentile JE, Reece SE. Daily rhythms in mosquitoes and their consequences for malaria transmission. Insects. 2016;7(2):1-20.

18. Omukunda E, Githeko A, Ndong'a MF, Mushinzimana E, Yan G. Effect of swamp cultivation on distribution of anopheline larval habitats in Western Kenya. J Vector Borne Dis. 2012;49(2):61-71.

19. Brant HL, Ewers RM, Vythilingam I, Drakeley C, Benedick S, Mumford JD. Vertical stratification of adult mosquitoes (Diptera: Culicidae) within a tropical rainforest in Sabah, Malaysia. Malar J. 2016;15(1):1-9.

20. Beck T. Will malaria soon be a thing of the past ? Natl Cent Biotechnol Inf. 2006;(2):1-6.

21. Kaur G. Malaria endemicity in an Orang Asli community in Pahang, Malaysia. Trop Biomed. 2009;26(1):57-66.

22. Aschale Y, Mengist A, Bitew A, Kassie B, Talie A. Prevalence of malaria and associated risk factors among asymptomatic migrant laborers in West Armachiho District, Northwest Ethiopia. Res Rep Trop Med. 2018;Volume 9:95-101.

23. Rowe AK, Rowe SY, Snow RW, Korenromp EL, Schellenberg A, Stein C, et al. Europe PMC Funders Group The burden of malaria mortality among African children in the year 2000. Int J Epidemiol. 2013;35(3):691-704. 
24. Wongsrichanalai C, Barcus MJ, Muth S, Sutamihardja A, Wernsdorfer WH. A Review of Malaria Diagnostic Tools : Microscopy and Rapid Diagnostic Test ( RDT ). Am Soc Trop Med Hyg A. 2007;77(2):119-27.

25. Singh B, Daneshvar C. Human infections and detection of plasmodium knowlesi. Clin Microbiol Rev. 2013;26(2):165-84.

26. Tan CH, Vythilingam I, Matusop A, Chan ST, Singh B. Bionomics of Anopheles latens in Kapit, Sarawak, Malaysian Borneo in relation to the transmission of zoonotic simian malaria parasite Plasmodium knowlesi. Malar J. 2008;7:1-8.

27. Figtree M, Lee R, Bain L, Kennedy T, Mackertich S, Urban M, et al. Plasmodium knowlesi in human, Indonesian Borneo. Emerg Infect Dis. 2010;16(4):672-4.

28. Milner DA. Malaria pathogenesis. Cold Spring Harb Perspect Med. 2018;8(1):1-11.

29. Okell LC, Bousema T, Griffin JT, Ouédraogo AL, Ghani AC, Drakeley CJ. Factors determining the occurrence of submicroscopic malaria infections and their relevance for control. Nat Commun. 2012;3:1-9.

30. Lindblade KA, Steinhardt L, Samuels A, Kachur SP, Slutsker L. The silent threat: Asymptomatic parasitemia and malaria transmission. Expert Rev Anti Infect Ther. 2013;11(6):623-39.

31. Report C, In N, With O. G Reek W Oman With S Plenomegaly. 1998;367-71.

32. Tantiamornkul K, Pumpaibool T, Piriyapongsa J, Culleton R, Lek-Uthai U. The prevalence of molecular markers of drug resistance in Plasmodium vivax from the border regions of Thailand in 2008 and 2014. Int J Parasitol Drugs Drug Resist [Internet]. 2018;8(2):229-37. Available from: https://doi.org/10.1016/j.ijpddr.2018.04.003 